\title{
MYASTHENIA GRAVIS ASSOCIATED WITH THYMOMA AND APLASTIC ANEMIA: CASE REPORT
}

\author{
Lidija Dežmalj Grbelja ${ }^{1}$, Radovan $\operatorname{Vrhovac}^{2}$ and Monika Ulamec ${ }^{3}$ \\ ${ }^{1}$ University Department of Neurology, Sestre milosrdnice University Hospital Center, Zagreb, Croatia; \\ ${ }^{2}$ University Department of Hematology, Zagreb University Hospital Center, Zagreb, Croatia; \\ ${ }^{3}$ University Department of Pathology, Sestre milosrdnice University Hospital Center, Zagreb, Croatia
}

\begin{abstract}
SUMMARY - Myasthenia gravis is associated in 10 to 15 percent of patients with thymic tumors, rarely with aplastic anemia. We report a 45-year-old male diagnosed with myasthenia gravis associated with thymoma. We started treatment with pyridostigmine. After thymectomy, the patient received 30 irradiation sessions. In the postoperative course, he had mild worsening of myasthenia gravis, which improved with prednisone. Five months later, he developed severe aplastic anemia. He was dependent on blood supplement. After allogeneic transplantation of bone marrow, he improved but later he developed graft versus host disease. Myasthenia gravis was under good control with $480 \mathrm{mg}$ of pyridostigmine per day.
\end{abstract}

Key words: Myasthenia gravis; Anemia, aplastic; Thymoma; Pyridostigmine bromide; Thymectomy; Prednisone; Transplantation, homologous; Graft ws host disease

\section{Introduction}

Myasthenia gravis (MG) is an autoimmune disease characterized by muscle weakness which results from blockade of the acetylcholine receptors (AChR) by antibodies and destruction of the receptors on the postsynaptic membrane. In 10 to 15 percent of patients with $\mathrm{MG}$, thymic tumors occur, while in 65 percent lymphofollicular hyperplasia of the thymic medulla is found. Thymoma with malignant characteristics may spread locally into the mediastinum and to regional lymph nodes but rarely metastasizes. Thyrotoxicosis is seen in 5 percent of myasthenic patients, and other autoimmune diseases such as systemic lupus erythematosus, rheumatoid arthritis, Sjögren syndrome, mixed connective tissue disease, polymyositis and aplastic anemia can be associated with MG.

Correspondence to: Lidija Dežmalj Grbelja, $M D$, University Department of Neurology, Sestre milosrdnice University Hospital Center, Vinogradska c. 29, HR-10000 Zagreb, Croatia

E-mail: lidija.dezmaljgrbelja@gmail.com

Received February 10, 2016, accepted April 27, 2016

\section{Case Report}

A 45-year-old male patient was admitted because of muscle weakness, speech and swallowing difficulties and breathing problems during physical activity persisting for several months. Previous history revealed high-grade myopia (-10 and $-16 \mathrm{dpt}$ ); in younger age he had undergone surgical treatment of inguinal and scrotal hernia. At the age of 43 , he had experienced minor head trauma with anxious depressive syndrome as a consequence, which was an obvious reason why his difficulties initially were considered as somatization. He had chronic low back pain and in 2007 thyroid adenoma with elevated T4 was found. He had lost approximately $20 \mathrm{~kg}$ in the previous year. He was a nonsmoker and did not take alcohol.

He presented with ptosis of the right eyelid, reduced muscle strength of the right arm and both legs, and hypotrophy of both hands and shoulders. Diagnostic procedure included standard blood tests, which were normal including thyroid hormones, electrolytes and tumor markers. Brain computed tomography 


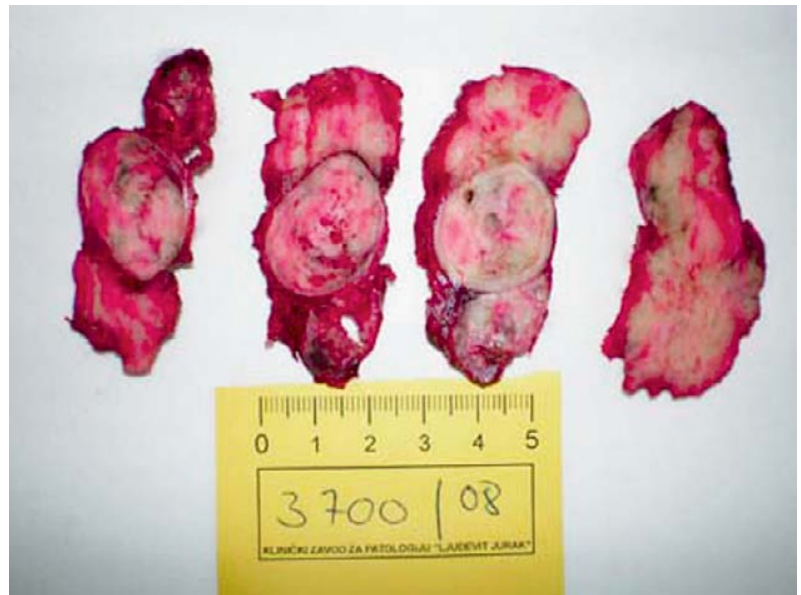

Fig. 1. Well-defined, encapsulated grayish tumor with a thick fibrous capsule.

(CT) scan was normal. Prostigmin test and repetitive nerve stimulation test were positive showing postsynaptic dysfunction of neuromuscular junction. While chest $\mathrm{x}$-ray was normal, CT scan of mediastinum showed a thymoma, $6 \times 3.5 \mathrm{~cm}$ in diameter. $\mathrm{AChR}$ antibodies were positive, which confirmed the diagnosis of MG. We started treatment with pyridostigmine and recommended surgical extirpation of mediastinal tumor, which was done two weeks later (Fig. 1). Histopathologic finding showed infiltration with CD3+ lymphocytes, immunohistochemical analysis showed tumor cells positive for CK7 and CK-PAN and focally positive for $\mathrm{p}-53$ and blc-2, suggesting thymoma B1 according to the World Health Organization (WHO) or predominantly cortical type according to the classification by Marino and Müller-Hermelink (Fig. 2). In the postoperative course, the patient had mild worsening of MG but improved with prednisone. Then radiation therapy in a total dose of $60 \mathrm{~Gy}$ in 30 fractions was administered because of infiltration of the capsule and adjacent adipose tissue with tumor cells. CT following therapy was found to be normal. Five months later, he presented with petechiae, epistaxis and gum bleeding. Laboratory findings revealed thrombocytopenia and anemia (erythrocytes (E) $2.97 \times 10^{12}$, hemoglobin $(\mathrm{Hb}) 86 \mathrm{~g} / \mathrm{L}$, platelets $(\mathrm{Plt})$ $34 \times 10^{9}$, and leukocytes (L) 7.0x109 ). Cytologic analysis of bone marrow and peripheral blood revealed intermediate hematopoiesis with predominance of granulocytopoiesis, while megakariocytes and cells of erythropoiesis were absent. Immunologic tests did not con-

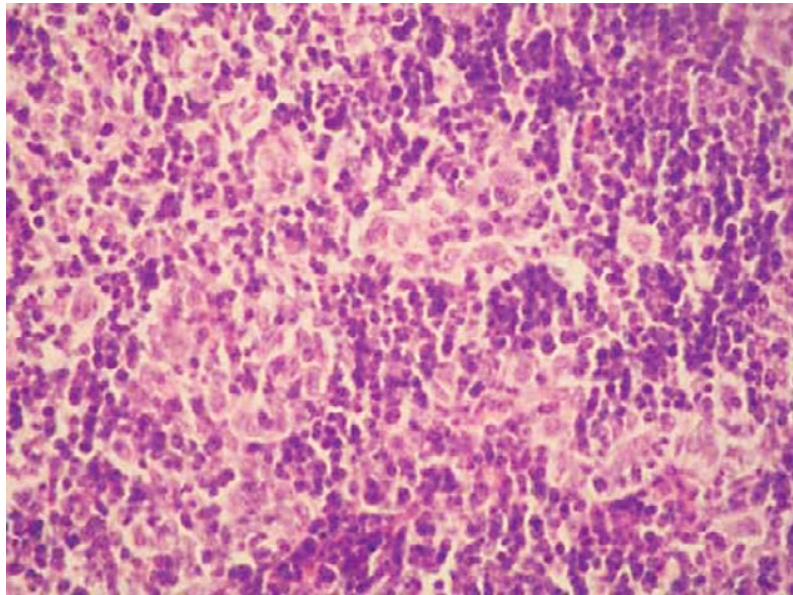

Fig. 2. Microscopically, interspersed monomorphous oval cells with pale round nuclei and small nucleoli surrounded by dispersed, densely packed population of small

lymphocytes (HE, X400).

firm autoimmune disease. Follow up CT scan of mediastinum did not show any sign of residual or relapsed tumor mass. The patient was initially treated with methylpredinisolone in a dosage of $1 \mathrm{~g} / 5$ days, followed by immunoglobulins in a dosage of $40 \mathrm{~g} / 5$ days, and finally with plasma exchange but without any improvement. The patient remained transfusion dependent and developed iatrogenic diabetes, treated with gliclazide. Further treatment with azathioprine, methylprednisolone and pyridostigmine was recommended. There was no sign of MG worsening. Two weeks later, fever, respiratory infection and significant anemia and thrombocytopenia occurred. Laboratory findings showed elevated erythrocyte sedimentation rate (ESR), leukopenia, anemia and thrombocytopenia (ESR 73, L 2.5, E 2.66, Hb 87, Plt 12). Immunologic tests including antinuclear antibodies (ANA), antineutrophil cytoplasmic antibodies (ANCA), lupus anticoagulant test, cardiolipin antibodies, rheumatoid factor and complement tests were normal. Cytologic analysis of bone marrow showed normal granulocytopoiesis, while erythropoiesis and thrombocytopoiesis were absent. Treatment with rituximab $100 \mathrm{mg}$ once a week was started; since no improvement was noted after 4 weeks with bleeding complications and transfusion dependence, a decision was made to proceed to bone marrow transplantation. HLA typing was done, followed by matched related allogeneic peripheral blood stem cell transplantation, with his sister being 
the donor. He experienced acute graft versus host disease (GVHD), which was treated with corticosteroids. Fourteen months later, macular skin exanthema occurred. Laboratory findings were normal except for elevated liver enzymes (E 4.71, Hb 142, Plt 142, L10.85, aspartate transaminase $87 \mathrm{U} / \mathrm{L}$, alanine transaminase $82 \mathrm{U} / \mathrm{L}$, gamma-glutamyltransferase 437 U/L). Liver biopsy was done showing chronic active hepatitis within GVHD, which improved after corticosteroid treatment. Three months later, Epstein-Barr (EBV) viremia was found and he received rituximab until viral clearance, in order to prevent posttransplantation lymphoproliferative disease. MG remained under good control over the mentioned period with 480 $\mathrm{mg}$ of pyridostigmine per day.

\section{Discussion}

We report a case of a 45-year-old male patient with a complex autoimmune neuromuscular disorder associated with thymoma and complicated with severe aplastic anemia after thymectomy, which was refractory to standard medical treatment with corticosteroids, immunoglobulins and plasma exchange. It is well known that thymoma can be complicated with MG and that MG is associated with thymoma, but development of aplastic anemia in these patients is a rare condition. Aplastic anemia usually precedes the diagnosis of thymoma. There have been only three cases described in the literature of aplastic anemia occurring as a late complication after thymectomy with the time interval between 3 and 48 months ${ }^{1-3}$. Ritchie et al. described a single case of MG and aplastic anemia after thymectomy and remission of thymoma ${ }^{4}$. Suzuki et al. found that 4 of 135 (2.9\%) patients with MG had pure red cell aplasia (PRCA) after thymectomy ${ }^{5}$. PRCA is also known as a concomitant disorder with MG. They concluded that thymoma, bulbar involvement and high level of AChR antibodies were significantly higher in patients with PRCA. Kobayashi et al. report a case of a patient with MG, thymoma, thrombocytopenia and granulocytopenia ${ }^{6}$. After thymectomy, not only the symptoms of MG but also hematologic findings improved. They also found that serum level of $\mathrm{p}$-ANCA against myeloperoxidase of granulocytes dramatically decreased after thymectomy, showing significant correlation with the granulocyte count. Conclusion was that $\mathrm{p}-\mathrm{ANCA}$ could be regu- lated by thymoma, leading to severe granulocytopenia. According to the staging system, thymomas are classified as stage I when completely encapsulated, stage II when extending through the capsule and with pericapsular fat invasion, stage III when characterized by invasion of adjacent structures, and stage IV when showing thoracic dissemination or metastases. The classification by Marino and Müller-Hermelink distinguishes medullary, mixed, predominantly cortical, cortical thymoma, well-differentiated thymic carcinoma, and other rare types of thymic carcinoma ${ }^{7}$. These types differ according to invasiveness, prognosis and association with MG. Medullary and mixed thymomas are rarely associated with $\mathrm{MG}$, while medullary type is most frequently associated with hematologic disorders. Cortical thymoma affects younger patients, shows more invasive nature, and is more frequently associated with MG. The occurrence of MG in a patient with thymoma usually precedes the diagnosis of thymic neoplasm. In the Mayo Clinic, 40\% of 283 patients presented with symptoms of tumor at the time of diagnosis, while $46 \%$ presented with symptoms of MG. Out of these patients, $29 \%$ had symptoms directly related to tumor.

Complete surgical resection is the gold standard in the treatment of thymoma. However, in advanced stage, complete resection may be difficult and recurrence is often recorded. In such cases, chemo- and radiotherapy after surgical treatment improve the prognosis. Also, in a tumor that is considered inoperable, induction radiotherapy applied before surgery improves the outcome. In a retrospective study, Vassiliou et al. showed that patients with MG and thymoma had a favorable outcome and that radiotherapy could be omitted in totally resected stage I-II patients, whereas it was beneficial in more advanced stages ${ }^{8}$. On the other hand, Mangi et al. showed that radiation did not prevent pleural recurrences in stage III 9 .

The course of the disease in the patient we presented is interesting because he had MG associated with thymoma and aplastic anemia as a late complication after thymectomy and remission of thymoma including a list of severe immune complications after allogeneic bone marrow transplantation. Despite hematologic, immunologic and infectious complications, prolonged corticosteroid treatment probably had a favorable effect on his neuromuscular disorder, since his MG showed no signs of worsening over time. 


\section{References}

1. Kobayashi H, Kitano K, Ishida F, et al. Aplastic anemia and idiopathic thrombocytopenic purpura with antibody to platelet glycoprotein IIb/IIIa following resection of malignant thymoma. Acta Haematol. 1993;90:42-5.

2. Dincol G, Saka B, Aktan M, et al. Very severe aplastic anemia following resection of lymphocytic thymoma: effectiveness of antilymphocyte globulin, cyclosporin A, and granulocyte-colony stimulating factor. Am J Hematol. 2000;64:78-81.

3. Socinski MA, Ershler WB, Frankel JP, et al. Pure red cell aplasia and myasthenia gravis. Coexistence of two diseases associated with thymoma. Arch Intern Med. 1983;143:543-6.

4. Ritchie DS, Underhill C, Grigg AP. Aplastic anemia as a late complication of thymoma in remission. Eur J Haematol. 2002; 68:389-91.
5. Suzuki S, Nogawa S, Tanaka K, Koto A, Fukuuchi Y, Kuwana M. Initial predictors of development of pure red cell aplasia in myasthenia gravis after thymectomy. Clin Neurol Neurosurg. 2003;106(1):16-8.

6. Kobayahi M, Hasegawa T, Iwabuchi S, Fukushima M, Koie H, Kannari K. The effect of thymectomy on myasthenia gravis, thrombocytopenia, and granulocytopenia associated with thymoma: report of a case. Surg Today. 1995;25(12):1061-5.

7. Suster S, Moran CA. Thymoma classification: current status and future trends. Am J Clin Pathol. 2006;125:542-54.

8. Vassiliou V,Tsamandas A, Katodritis N, et al. The role of postoperative radiotherapy in the management of patients with thymic tumors - a retrospective study. In Vivo. 2009;23(5):843-52.

9. Mangi AA, Wain JC, Donahue DM, Grillo Hc, Mathisen DJ, Wright CD. Adjuvant radiation of stage III thymoma: is it necessary? Ann Thorac Surg. 2005;79:1834-9.

Sažetak

\section{MIASTENIJA GRAVIS UDRUŽENA S TIMOMOM I APLASTIČNOM ANEMIJOM PRIKAZ SLUČAJA}

\section{Dežmalj Grbelja, R. Vrhovac i M. Ulamec}

Miastenija gravis (MG) je u 10\% do 15\% bolesnika udružena s tumorima timusa, rijetko s aplastičnom anemijom. Prikazujemo 45-godišnjeg bolesnika s MG udruženom s timomom. Liječenje je započeto piridostigminom. Nakon timektomije je provedeno 30 zračenja. Poslijeoperacijski je imao blago pogoršanje MG koje se povuklo uz terapiju prednizonom. Pet mjeseci kasnije je razvio tešku aplastičnu anemiju. Postao je ovisan u krvnim derivatima. Nakon alogenične transplantacije koštane srži došlo je do poboljšanja, ali je kasnije razvio reakciju transplantata protiv primatelja. MG je bila dobro kontrolirana uz $480 \mathrm{mg}$ piridostigmina na dan.

Ključne riječi: Miastenija gravis; Anemija, aplastična; Timom; Piridostigmin bromid; Timektomija; Prednison; Transplantacija, homologna; Transplantacijska bolest 